\title{
On Trade Barriers to China's Textiles Industry
}

\author{
Jing Ma \\ School of Economics and Management, Changchun University of Science and Technology \\ Weixing Road No. 7989, Changchun 130022, China \\ E-mail: majingdoll@hotmail.com
}

Weiquan Yang

Guanghua Business of Japan, Dalian Branch, Room 918, Minyong Building, Dalian 116001, China

Tel: 86-411-8973-3633Ｅ-mail: kokadl@163.com

\begin{abstract}
Firstly we shall introduce the development situation of China's textile industry from international trade perspective, and then analyze the current international trade competition focusing on international trade barriers which consist of tariff and non-tariff barriers respectively. Finally we propose that increasing non-tariff barriers to China's textile exportation are due to lower tariff, trade protection, rapid growth and keen competition of the industry.
\end{abstract}

Keywords: Trade barriers, Textiles industry, Exportation, China

\section{Introduction}

According to classical theories of international trade and global economy circumstances currently, free trade as one of the essential aims of WTO is the main tendency for international trade development. Therefore plenty of trade agreements among different countries and regions have led to lower, even no tariff in categories of products' importation and exportation. Nowadays tariff barrier is less important due to tariff agreements are rather apparent documentarily, thus no one would like to take this risk to limit importation. So a great deal of more flexible, more implicit non-tariff barriers, which are carried out to protect national industries and products, appeared subsequently.

China's textile industry with long history and high reputation in the world plays important role in economics development and foreign trade in China. Taking advantage of low labour cost as one of basic factor, China's textile industry improves rapidly and deeply in different aspects, such as owner's structure, regions structure, investments structure, consumptions structure, markets structure, and technology structure. But it also has to face the keen competition in the world market and trade restriction from some developed countries.

\section{China's Textiles Trade and Competitive Status}

The incremental exportation is one of the significant impetuses of getting the rapid development in textile industry. With the promotion of integrated international textiles trade, textiles industry is more and more dependent on global markets. It is very necessary to analyze and evaluate China's textiles industry within the world market environments from international perspective, and find how China textiles trade is going on, where the position of China's textiles industry is, and how to reform and adjust it.

\subsection{Trade Scale and the Position in World Market}

\subsubsection{Trade Scale and Importation and Exportation Structure}

Textiles and clothing industry of China is going on with relative large surplus. But the advantages are limited in medium-and-low grade products, and deficits exist in wool, fabrics, bombazine, worsted, high grade textiles and apparel, and so on. China's textiles industrial structure and products structure are rather weak. And one of the disadvantages in China's textiles industry is the low capacity in producing high technology involved up-and-medium products (Yonghui Xu, 2003).

\subsubsection{China's Textiles Industry's Status in World Market}

China's textiles and clothing play important role in world market, which hold a large global share in many categories. And US are the second largest textiles and clothing market in world market, followed by Japan, ranking third. Also China is the biggest textiles supplier to Japan, and second to USA which is the second 
biggest textiles and clothing market. In fact, EU is the biggest cake here; however its member countries shared most of the market, leaving very small room for China compared to Japan and USA. Anyway it is the most attractive textiles and clothing market thanks to the big consumption capacity.

In 2005 China gross imp. \& exp. value of textile and apparel reached 134.634 billion dollars, increasing $17.90 \%$ compared with the same period of last year, and taking up $9.47 \%$ of China gross imp. \& exp. value of foreign trade. Gross export value of textile and apparel in China was up to 117.535 billion dollars, increasing $20.69 \%$ compared with the same period of last year, and taking up $15.42 \%$ of gross export value of foreign trade in China. Among them, textile export was 43.969 billion dollars, increasing $22.93 \%$ compared with the same period of last year; and apparel export was 73.566 billion dollars, increasing $19.40 \%$ compared with the same period of last year. Gross import value of textile and apparel reached 17.099 billion dollars, increasing $1.76 \%$ compared with the same period of last year, and taking up $2.59 \%$ of gross import value of foreign trade in China. Among them, textile import was 15.490 billion dollars, increasing $1.42 \%$ compared with the same period of last year; while apparel import was 16.09 billion dollars, increasing 5.08\% compared with the same period of last year. Through Jan.-Dec.2005, favorable balance of textile and apparel trade reached 100.436 billion dollars.

Among main export countries and areas of textile and apparel, U.S. became top one, Japan and Hong Kong was the top two \& top three. Through Jan.-Dec.2005, China exported to USA reached 19.576 billion dollars, increasing $66.09 \%$ compared with the same period of last year; export to Japan was 18.10 billion dollars, increasing $5.54 \%$ compared with the same period of last year; export to Hong Kong was up to 14.843 billion dollars, down $14.59 \%$ compared with the same period of last year. Total value of export to the three regions reached 52.522 billion dollars, taking up $44.69 \%$ of total export of textile and apparel. Export to EU in 2005 reached 188.63 billion dollars, increasing $55.30 \%$ compared with the same period of last year. Export to USA \& EU reached 38.439 billion dollars, increasing $60.02 \%$ compared with the same period of last year.

Among main import countries and areas, Japan, Taiwan area and South Korea became top three. Through Jan.-Dec.2005, import textile and apparel from Japan, Taiwan, and South Korea was 3.362 billion dollars, 3.212 billion dollars, and 2.631 billion dollars, falling $4.12 \%, 2.61 \%$, and increasing 1.18\% separately. (Sub-Council of Textile Industry, China Council for the Promotion of International Trade)

\subsection{Competition of China's Textiles Exportation}

\subsubsection{Price Competition}

Price advantage is one of the primary reasons of rapid growth in China's textiles products exportation; furthermore it will be the dominant factor for promoting exportation growth in the near future. But price competition deteriorated terms of trade gradually. Also costs advantage has not been transferred into profits advantage (Jiagui Chen \& Chang Zhang, 2002). Actually price competition T\&C industry mostly derives from low labor costs, while for China this advantage is weakening due to the competition from some developing countries with even lower salaries.

\subsubsection{Non-Price Competition}

Non-price competition consists of quality competition, non-quality competition and technique competition (Jiagui Chen \& Chang Zhang, 2002). With the updating of consumption tendency, products should be more advanced and differentiated. Switching from price competition to non-price competition is the fundamental step to implement products differentiation strategy. While China' T\&C industry has low non-price competition, with low capacity in producing high value-added products as a result. In quality facet, quality management system and quality control and evaluation system could catch up with the process of internationalization and products periodization. Non-quality competition includes fashion style, marketing, and services after sale, company image, management, branding and so on. With respect to textiles products, particularly clothing, fashion i.e. seeming value is the basic factor concerning quality. Seeming value demand, which is the main factor for creating high value chain, is much dependent on income elasticity and little dependent on price elasticity. The value of textiles and clothing consists of not only costs but also seeming value. Seeming value is together with design, so that in industrial countries fashion designs are highly emphasized on, with differentiation rate of $65 \%$. But there are relevant scarce human resources in products scheme and fashion design. Exportation of domestic brands account for low percentage, while international up-to-date styles enjoy great popularity in China. Regarding to technique competition, China has been catching up with industrial countries in synthetic fabrics and cotton textiles productions skill. Nevertheless there is still big gap in new synthetic fabrics technique and hyper speed spinning level between them. It is hard to obtain core technique without enough $R \& D$ investment. So it is very important to accumulate experiences and skills by hard working in order to lessen technique disparity. 


\subsubsection{Branding competition of Silk Products}

Chinese silk products enjoy great popularity for years all over the world as traditional China's exporting products. China is a big exporting country of silk products, accounting for $75 \%$ of silk manufacturing in the world. In the global market, Chinese raw silk and broadloom exportation account for more than $90 \%$ and $50 \%$ respectively, as well as silk apparel with quite high proportion. Splendid and elegant Chinese silk with strong cultural characteristics are preferred by many international famous textile manufacturers. Nowadays many industrial countries mainly produce fashion-oriented and personality-oriented clothing products with high quality and at high price. But in China the textiles products in low and middle grade are still the main stream. For instance, the profits by selling a silk tie of popular brand made in Italy could be ten times than that in China. Therefore it is already taken into account how to change China from 'big silk country' into 'competitive silk country', and how to change Chinese silk products from cheap 'FAQ' to high quality 'branded products'. Also it is announced in 'China silk industry in the tenth five-year programme' that silk branding strategy will be implemented and a series of famous silk brands will grow up year after year. It is an essential threshold to become 'competitive silk country' for China, and means China will begin to develop silk products industry mainly with final products and famous brands. In short, establishing silk brand is the wise way for China to develop silk and clothing industry. Efforts should be made to carry out branding strategy, enhance exporting structure, increase products' value, improve exquisite crafts, etc. so as to explore international silk market. (Caifa Song, 2004)

\section{Trade Barriers on Exportation}

\subsection{Tariffs Trade Barriers}

Tariffs may be designed to collect revenue for the government or to protect domestic industries against foreign competition (Franklin, 1994). In order to perform revenue function better, governments have to set the tariffs rates on proper level (not too high actually) to maximize tariffs revenue. Thus import tariffs applied by this purpose can not be regarded as tariff barriers. As tools of national economics policy designed to regulate the international trade of a nation, normal tariffs collections are commonly acceptable methods also, especially in previous industries age. Actually only those extremely high and additional import tariffs as quantitative measures of restriction are the real tariffs barriers, i.e. surcharges with emergency, short-lived character.

After acceding to WTO formally in 2001, China could benefit from trade liberalization and greatly improved market accession. The positive influences on textiles trade have been bringing new opportunity. However, up to now industrial countries keep the average tariff rate on manufactured products around $5 \%$, while tariff peak on textiles. Taking the main textiles importing countries from China for instance, import tariff on textiles is four times than average tariff in USA, $10 \%$ in EU and $8.5 \%$ in Japan with tariff escalation, which hinders well manufactured products.

\subsection{Non-Tariff Trade Barriers}

As the industrial countries have progressively cut tariff rates under the auspices of the GATT and WTO, non-tariff trade barriers have become more and more prominent, and are used more generally and frequently.

\subsubsection{Import Quotas}

Import quotas are applied in three major types throughout the world, i.e. unilateral quotas, negotiated bilateral or multilateral quotas, and tariff quotas. In the last few years by the end of 20 century China faces strong restrictions on its exports of textiles and clothing products to the four trading partners that maintain import quotas, namely the United States, European Union, Canada and Norway (Cass, 2003). Import quotas policy is commonly regarded as the biggest barrier in global free trade on textiles products previously, but it is limited and abolished gradually for general disapproval on unilateral or multilateral negotiations in WTO in recent years. Since 1 January 1995, international textiles and clothing trade has been going through fundamental change under the 10-year transitional programme of the WTO's Agreement on Textiles and Clothing (ATC). Before the Agreement took effect, a large portion of textiles and clothing exports from developing countries to the industrial countries was subject to quotas under a special regime outside normal GATT rules. Under the Agreement, WTO Members have committed themselves to remove the quotas by 1 January 2005 by integrating the sector fully into GATT rules.

Moreover it is commonly considered that China is the biggest beneficiary by abolishing import quotas on textiles and clothing by the end of 2004 according to ATC. The main American Textile Consortium and Labour Union contend the incremental growth in Chinese Textile industry will cause $75 \%$ unemployment among 702 thousand weavers in US in the coming couple of years. In fact, American employment in textiles and clothing industry 
decreased already by $30 \%$ and $50 \%$ respectively during $1980-2000$ (Bernard, 2001). Actually it is the normal phenomenon incurred in the more equal and more impartial competition environments in the world market. Also not only Chinese textile enterprises that benefit from incremental textiles exportation, but also plenty of foreign investors in textiles and clothing industry, international buyers and numerous consumers.

\subsubsection{Anti-Dumping}

According to the 'Agreement on implementation of Article VI of the General Agreement on Tariffs and Trade 1994' dumping exists 'if the export price of the product exported from one country to another is less than the comparable price, in the ordinary course of trade, for the product when destined for consumption in the exporting country(Jepma \& Rhoen, 1996)'.

Dumping and anti-dumping have already been significantly global issues in recent years. As a type of legal tool to maintain impartial trade within the framework of WTO anti-dumping is frequently applied by many countries to protect domestic industries and markets. Chinese textiles and clothing exportation incurred anti-dumping lawsuits from different developed countries and developing countries. Developed countries seldom raised anti-dumping lawsuits on Chinese exportation of textiles and clothing previously due to commonly used import quotas restrictions. However it does not mean they will behave as before after quotas' disappearance some day in the future. On the contrary, some developing raised more and more anti-dumping lawsuits on it, moreover account for larger proportion. From economics perspective, when import country and export country have similar factor proportion, the competition advantage on trade mainly depends on economies of scale, products differentiation and market structure (Jepma \& Rhoen, 1996). For many developing countries, textiles and clothing industry played important role in primary age of economics development and the process of industrialization. Due to the imbalance in developing industrialization, some developing countries with the same factor proportion as China began to import Chinese textiles products characterized with economies of scale and uniqueness since 1990s', meanwhile the disputes on anti-dumping are more and more intense, such as the lawsuits from Mexico, Chile, Argentina, Venezuela, Colombia and so on, accounting for $57 \%$ already among global anti-dumping lawsuits to Chinese textiles exportation.

China has not been acknowledged as the country of market-oriented economy by some developed countries up to now. Actually this issue is quite important in anti-dumping investigation with regard to price comparisons. The prices of similar products in substitute countries are applied, instead of the prices in domestic market, to confirm dumping on condition that China is not a completely market-oriented country. Consequently many Chinese enterprises including textiles companies incurred big losses due to the assumed prices.

\subsubsection{Green Trade Barrier}

During the developing process of the world trade liberalization, green trade barrier is now becoming a new non-tariff trade barrier along with the gradually weakening of the traditional trade barriers. Some industrial countries have been accelerating construction of green barrier, for example in textiles and clothing trade filed, ten more new regulations or rules came up in 2002. Green barriers are being extended to authentications of textiles and clothing products. Currently more than forty countries are carrying out 'green' marks authentications, that is to say products will be allowed to enter domestic market as long as it has 'green mark'. Exporters have to apply for these marks from import country, through strict inspections, tests, thorough evaluation and pay some fees after getting pass. Usually there is time of validity to use these marks, so that they must apply for them once again after the expire date. There are several main trade barriers nowadays, such as ISO9000 quality management certificate, ISO14000 environment management certificate and Europe Ecological textiles mark. But Chinese enterprises have not been paying so enough attention to these authentications that around $70 \%$ export companies and $25 \%$ products in textiles industry were influenced by technique barriers in 2000 , loosing 1 million US $\$$ as result. So countermeasures are being carried out to meet different requirements in the certificates (Hao \& Gu, 2003).

\subsubsection{Other Trade Restrictions}

Because of its high domestic unemployment rate and withering textile industry, US government has been limiting China's export of textile products to US since 2001, using the "special protection clause" in Sino-US agreement on China's entry into WTO as a pretense. In essence, the practice is a kind of protectionism. It is an unwise decision and will impede the healthy development of trade between China and the U.S.A.

US Issued the latest Report on Export of Restricted Textile Products before Mar.10, 2006. US has begun to impose tight quotas on 22 catalogs of Chinese textiles and apparel from Jan.1, 2006 to the end of this year, 
including (338/339) cotton knit shirts, (347/348) cotton trousers, (352/652) cotton \& fiber underwear, (638/639) fiber knit shirts, (647/648) fiber trousers, (340/640) cotton \& fiber tat shirts, (301) combed cotton yarn and so on.

\section{Conclusion}

The classical theories of international trade could explain the basic reason of trade across borders from economics perspective on condition of certain hypotheses. The advantages and disadvantages of China's textiles industry could be found by theories reviewing, which are helpful to reform and strengthen international trade conditions of textiles products. But theories have to be associated with practices no matter it is perfect or not.

After several-round hard negotiations on GATT, and the following WTO as well, China became the formal member of WTO on $11^{\text {th }}$, December 2001 finally. But it does not mean China's T\&C trade would benefit from it for sure without any restriction. Obviously for China it is not only a good chance must be taken to develop national economy and international communications but also a big challenge that China has to confront anyway. Although tariff trade barrier is less and less important for China T\&C trade due to ATC, non-tariff trade barriers have been becoming more effective subsequently, especially in the main industrial countries. Countermeasures to these problems are being proposed one after another.

\section{References}

Bernard A. Gelb. (2001). Textile and Apparel Trade Issues. Congressional Research Service Report for Congress. RS20436. p2.

Caifa Song. (2004). WTO regulations and China textiles and clothing brand protection. South-West National University. Chengdu. China.

Cass, Deborah. (2003). China and the World Trading System: Entering the New Millennium. West Nyack. NY. USA. Cambridge University Press.

Chen Jiagui \& Zhang Chang. (2002). Profit advantage-Comparisons of Sino-US competitive industries. International Trade. Vol 5.

Hao Weimin \& Gu Qiang. (2003). International competition environment for textiles industry and countermeasures. International Economy Cooperation, pp. 14-17.

Jepma, Catrinus \& Rhoen, Andre. (1996). International trade: a business perspective. Open University of the Netherlands Heerlen.

Li Ting. (2003). ATC and anti-dumping issues in Chinese textile trade. Dong Hua University Journals. Social Science.

Peter Kilduff. (1998). An Overview of the Competitive Dynamics of the Global Textile and Apparel Industries. University of Leeds. Textile Intelligence Center.

Root, Franklin R. (1994). International Trade and Investment, seventh edition. The Wharton School University of Pennsylvania. South-Western Publishing Co.

Shen Yao. (1999). Economics Analysis on dumping and anti-dumping. Hang Zhou. Zhejiang University Publication House. pp. 177-124.

$\mathrm{Xu}$ Yonghui. (2003). The changing of international textiles \& clothing market and the countermeasures of China's textiles industry. Social Science frontier. pp. 27-33. 